\title{
Integrated modifying zinc-containing additive for construction silicate compositions
}

\author{
Yuri Ivaschenko, Maria Kochergina ${ }^{*}$, Irina Pavlova and Natalya Fomina \\ Yuri Gagarin State Technical University of Saratov, Department "Building Materials and \\ Technologies", Polytechnic St., 77, Saratov, Russia
}

\begin{abstract}
Sodium silicate binders are a promising binder base for obtaining effective granular thermal insulation materials. Increasing water resistance, first of all, will expand the scope of their application in construction. At the same time, the features of the modification of sodium silicate binders by compounds of polyvalent metals have not been fully studied, the interaction with which leads to the formation of hardly soluble silicates. The purpose of this work was to develop a modifying complex based on a zinc-containing compound - zinc acetate to increase the water resistance and thermal characteristics of the porous granular material. The proposed modifying additive is a complex consisting of zinc acetate and an organic alcohol solvent. It is shown that the properties of porous granular material can be controlled by changing the composition of the zinc acetate solvent. Qualitative and quantitative dependences of the properties of porous granules (strength, water resistance, density, thermal conductivity) on the type of zinc-containing solution and its content in the compositions have been obtained. The concept of the mechanism of formation of sparingly soluble complexes during the modification of sodium silicate binders with zinc-containing aqueous-alcoholic solutions has been developed. X-ray phase analysis showed that the sodium silicate system modified with an aqueous alcohol solution of zinc acetate, in contrast to an aqueous solution of zinc acetate, is completely in an amorphous state. We believe that compounds of the $\mathrm{Zn}_{2} \mathrm{SiO}_{4} \mathrm{H}_{2} \mathrm{O}, \mathrm{ZnSiO}_{3}$ type are in the amorphous state. The obtained research results made it possible to determine the rational composition of granular heat-insulating material with increased operational and functional characteristics $\left(\rho=200-280 \mathrm{~kg} / \mathrm{m}^{3}, \lambda=0.052-0.063 \mathrm{~W} /\left(\mathrm{m}^{\circ} \mathrm{C}\right), \quad \mathrm{R}=1.3-1.8 \mathrm{MPa}\right.$, $\left.\mathrm{K}_{\mathrm{r}}=0.89-0.92, \mathrm{~W}=16-18 \%\right)$.
\end{abstract}

\section{Introduction}

Sodium silicate binders (SSB), which are capable of maintaining a viscous state at the preparation stage of a raw mixture, provide a promising binder for obtaining effective granular insulation materials. However, they have not reached a large used in industry. This is mainly result of the relatively low water resistance and lack of knowledge of the patterns of formation in the modification [1-9]. Promising studies are studies on the pattern of

\footnotetext{
*Corresponding author: m-kochergina@list.ru
} 
modification of the SSB by polyvalent metal compounds. When they interact with the silicate system, they are capable of assembling intractable compounds. Analysis of the scientific and technical literature has shown that increasing the water resistance of silicatesodium materials is achieved by modifying the SSB with polyvalent metal oxides and hydroxides [8, 10-14].

Previously, the work [15-19] showed that when the SSB was modified with $24 \%$ water solution of zinc acetate (7-10\% by mass of binder), the following basic granulate parameters can be reached: $\rho=370-405 \kappa \Gamma / \mathrm{M}^{3}, \mathrm{R}=2.34-2.58, \mathrm{~K}_{\mathrm{r}}=0.88-0.94$. X-ray lines identical to phases shall be recorded on the diffractograms of the corresponding samples: $\mathrm{ZnSiO}_{3}, \mathrm{Zn}_{2} \mathrm{SiO}_{4} \mathrm{H}_{2} \mathrm{O}, \mathrm{Zn}_{2} \mathrm{SiO}_{4}, \mathrm{ZnNa}_{2} \mathrm{SiO}_{4} \cdot \mathrm{mH}_{2} \mathrm{O}$. In addition, it has been found that as the content of the modifier in the compositions increases linearly, the bulk density increases. The creation of a denser structure in porous granules can be explained by the following. Silicon acid, which is additionally released as a result of the interaction between the SSB and the zinc-containing solution, contains silicon groups $(\equiv \mathrm{Si}-\mathrm{OH})$. The latter are capable of reacting to polycondensation by forming siloxane bonds ( $\equiv \mathrm{Si}-0-\mathrm{Si} \equiv$ ). The result is silicon acids with varying degrees of polymerization. As a result of the increase in polymerization, the viscosity of the modified silicate system is likely to increase significantly at the moment of the most intense discharge of vapours during heating.

It should be noted that, for this reason, the use of modifying additives causing acid polycondensation (zinc salts, aluminium, etc.) in the production of especially light silicate thermal insulation materials is restricted. In order to improve the thermal performance of porous grains, a scientific and technical solution is proposed, the justification for which is given below.

Currently, integrated additives (consisting of several components) or modifying complexes (the components of which are inserted in a binary matrix separately) are soughtwhich combine the merits of individual supplements and, where possible, either reinforce each other's actions or nullify their negative properties.

In theory, it is possible to reduce the bulk density and thus the thermal conductivity of the porous granules by reducing the filling content of the composition and by increasing the degree of porosity thereof. Correspondingly, the degree of filling can be reduced by introducing coagulant substances that increase the SSB viscosity. It is possible to increase porosity by using powder-forming substances.

The purpose of this was to develop a modifying complex based on a zinc-containing compound - zinc acetate to increase the water resistance and thermal characteristics of the porous granular material.

\section{Materials and Methods}

The main objects of the study were modified silicate-sodium compositions (SSC) on the basis of marketable liquid sodium glass, corresponding to GOST 13078-81 ( $\rho=1480 \mathrm{~kg} / \mathrm{m}^{3}$; silicate module $\mathrm{M}=2.7$ ). Organic zinc-containing compound - zinc acetate dihydrate (GOST 5823-78) was used as a modifier. Sodium silicofluoride was used as a hardener in the compositions (TU 6-09-05807960-114-94). Fine-milled flask with $\mathrm{S}=300-350 \mathrm{~m}^{2} / \mathrm{kg}$ were used as fillers. The solvents were considered to be alcohols from a number of single and multi-atomic alcohols.

The efficiency of use of the additive was evaluated by comparing the bulk density, heat conductivity, strength, water resistance and waterproofing of the porous granules with the control samples not modified. The water resistance of silicate-sodium composites was estimated by the value of the softening coefficient $\left(\mathrm{K}_{\mathrm{r}}\right)$, which is equal to the ratio of strength indicators $R_{\text {szh }}$ of samples in the water-saturated and initial state. The additive was produced in the following way $25 \mathrm{~g}$ of diphydrate ACs dissolved in $100 \mathrm{~g} 20 \%$ aqueous 
alcohol solution at room temperature. The compositions used a fine filler from a powder, a hardening accelerator - a sodium silica. Raw granules were pumped under microwave heating conditions with a microwave radiation of $850 \mathrm{~W}$ for 3 minutes.

\section{Results and Discussion}

Given the effective way of introducing zinc salt into the silicate system (in the form of aqueous solutions) [15-19], the solvents were considered to be alcohols from a number of single and multi-atomic alcohols. Spires can influence the viscosity-plastic properties of the $\mathrm{SSB}$, as well as being at the same time a powder-forming agent in the binder system.

Table 1. shows the physical properties of the alcoholic solvents used [20]. Studies have shown that single-atomic alcohols (ethyl, isopropyl) contribute more to the stiffness of the silicate solution. This results in a significantly higher ratio of binder/filler $(B / H)$ than double-atomic alcohol - diethylene glycol and multi-atomic alcohol - glycerine (Figure 1). At the same time, it must be noted that the coagulating capacity of alcohols is increased with the reduction of the value of surface tension $\sigma$, dielectric permeability $\varepsilon$, dipole moment of alcohol $\delta$.

Table 1. Physical constants of solvents

\begin{tabular}{|c|c|c|c|c|c|}
\hline Name of the solvent & 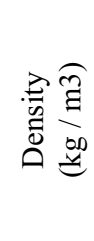 & 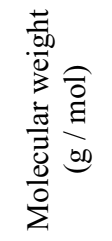 & 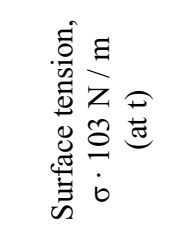 & 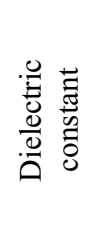 & 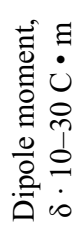 \\
\hline Ethyl alcohol (monohydric) & 789.3 & 46.069 & $22.03\left(20^{\circ} \mathrm{C}\right)$ & 24.3 & 1.68 \\
\hline $\begin{array}{c}\text { Isopropyl alcohol } \\
\text { (secondary monoatomic) }\end{array}$ & 785.1 & 60.09 & $21.7\left(18^{\circ} \mathrm{C}\right)$ & 18.62 & 1.66 \\
\hline $\begin{array}{l}\text { Diethylene glycol } \\
\text { (dihydric alcohol) }\end{array}$ & 1118 & 106.12 & $48.5\left(25^{\circ} \mathrm{C}\right)$ & 32.6 & 2.69 \\
\hline Glycerin (triatomic) & 1261 & 92.1 & $59.4\left(20^{\circ} \mathrm{C}\right)$ & 42.5 & 2.8 \\
\hline
\end{tabular}

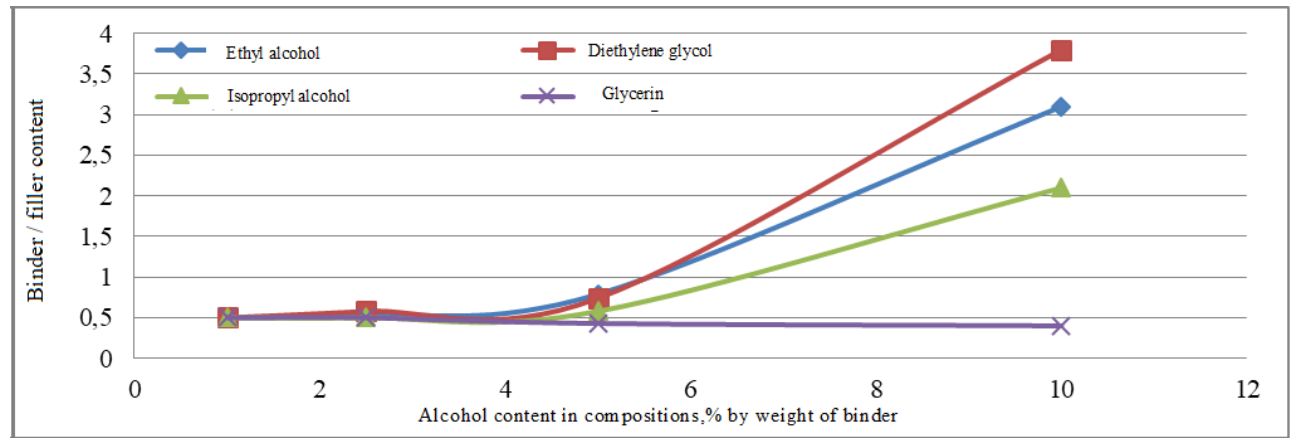

Fig. 1. Change in the degree of filling of sodium silicate compositions from the quantitative content of alcohol, $\%$ by weight of SSB 
Ethyl alcohol is the second solvent for zinc salt after water (4.38-5.82 g/100 g solvent). This primarily predetermines its use as a solvent. Since the solubility of zinc acetate in ethanol is slightly lower than in water, in order to achieve the highest concentration in the solution, $20 \%$ aqueous alcoholic solution was used in the study, which made it possible to dissolve up to $25 \mathrm{~g}$ of zinc salt per $100 \mathrm{~g}$ of solvent. The modifying additive is thus a complex consisting of thermally unstable zinc salt and organic alcohol solvent (ethanol).

The results of the study are shown in table 2. As expected, with the increase in the content of the SSB mass modifying zinc solution to the maximum possible limit, there is a decrease in the filling rate in the compositions (figure 2).

With this in mind, table 2 presents the most rational formulations for the main physical and mechanical parameters of granules. The composition of the study also varied with respect to the content of the silica sodium hardener, the rational quantity of which was based on the minimum bulk density and water loss of porous granules, received without pre-drying.

Table 2. Physical constants of solvents

\begin{tabular}{|c|c|c|c|c|c|c|c|}
\hline \multirow[t]{2}{*}{ Parameter name } & \multicolumn{6}{|c|}{$\begin{array}{c}\text { Values depending on the content of the modifier, } \% \\
\text { by weight of SNC }\end{array}$} & \multirow{10}{*}{ 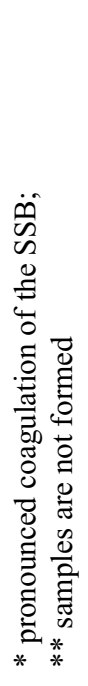 } \\
\hline & 0 & 5 & 7 & 10 & 12 & 15 & \\
\hline Density (bulk), $\mathrm{kg} / \mathrm{m}^{3}$ & 350 & 280 & 230 & 200 & 180 & - & \\
\hline $\begin{array}{l}\text { Coeff. thermal conductivity, } \\
\qquad \mathrm{W} /\left(\mathrm{m} \cdot{ }^{\circ} \mathrm{C}\right)\end{array}$ & 0.082 & 0.063 & 0.054 & 0.052 & 0.044 & - & \\
\hline $\begin{array}{l}\text { Strength Rczh in the cylinder, } \\
\qquad \mathrm{MPa}\end{array}$ & 2.29 & 2.04 & 1.56 & 1.3 & 1,1 & - & \\
\hline Softening factor & 0.71 & 0.79 & 0.83 & 0.87 & 0.82 & - & \\
\hline Water absorption by weight, $\%$ & 13.6 & 14.8 & 16,6 & 18 & 26.4 & - & \\
\hline Pot life of the mixture, min & 70 & 38 & 22 & 16 & 9 & - & \\
\hline $\begin{array}{l}\text { Rational maintenance of the } \\
\text { flask, } \% \text { by weight of SSB }\end{array}$ & 85 & 65 & 55 & 35 & $20 *$ & $* *$ & \\
\hline $\begin{array}{l}\text { Rational content of the } \\
\text { hardener, } \% \text { by weight of SSB }\end{array}$ & 10 & 7 & 7 & 5 & 5 & & \\
\hline
\end{tabular}

Thus, it has been experimentally established that, with an increase in the content of the modifying solution, the filling of the CNS with a fine-size plating is significantly reduced, which in the first place makes it possible to reduce the bulk density of the granules (Figure 2). The amount of the coefficient of heat conductivity is reduced, also due to the additional porosity of the hydrogel as a result of the evaporation of alcohol from the intermittent fluid during the heating process.

An aqueous-alcoholic zinc-containing solution with a rational composition (7-10\% by mass of the SSB) provides an increase in the water resistance of porous granules by $20 \%$ relative to the control composition (Figure 3). With this modifier content, the granular material has the following properties $\rho_{\mathrm{n}}=200-230 \mathrm{~kg} / \mathrm{m}^{3}, \lambda=0.052-0.064 \mathrm{~W} /\left(\mathrm{m}{ }^{\circ} \mathrm{C}\right)$, $\mathrm{R}=1.3-1.76 \mathrm{MPa}, \mathrm{W}=16.6-18 \%, \mathrm{~K}_{\mathrm{r}}=0.83-0.87$. When a modifier is introduced more than $12 \%$ there is a pronounced SNA coagulation, which causes the composition integrity to be disturbed. 


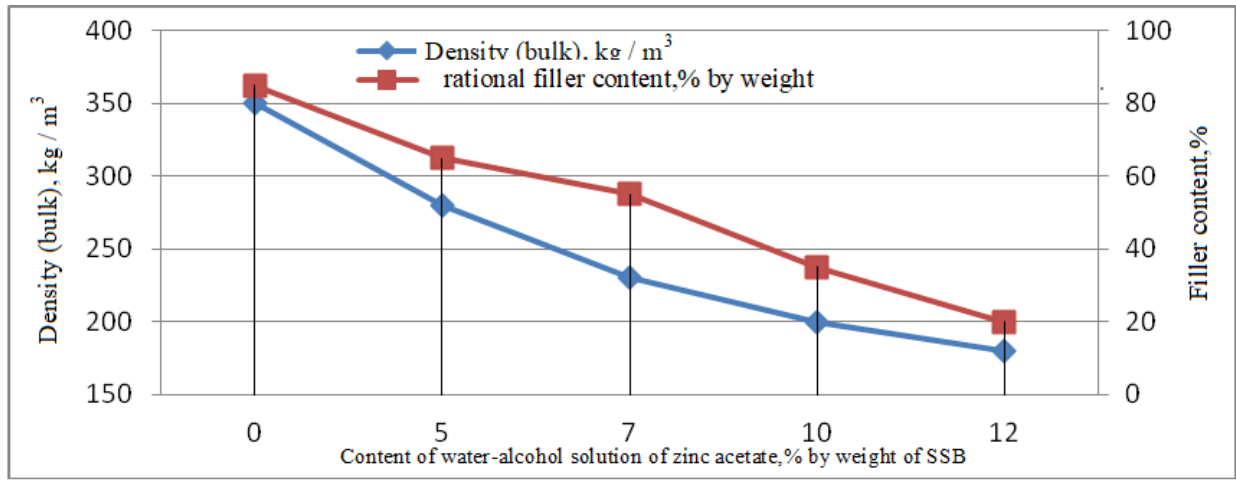

Fig. 2. Change in the degree of filling of the SNC and the bulk density of the granules from the content of the aqueous-alcoholic solution of AC,\% by weight of the SSB

It should be noted that in the course of the study, the positive effect of the combined improvement of the thermal and water-resistant characteristics of granules is revealed precisely when the SSB is modified in the form of an aqueous-alcoholic solution of zinc acetate. When modifying components (ethanol and zinc acetate aqueous solution) are introduced into the composition, a coarse structure in the volume of the pellet is formed separately. This results in reduced strength and increased water reading by mass.

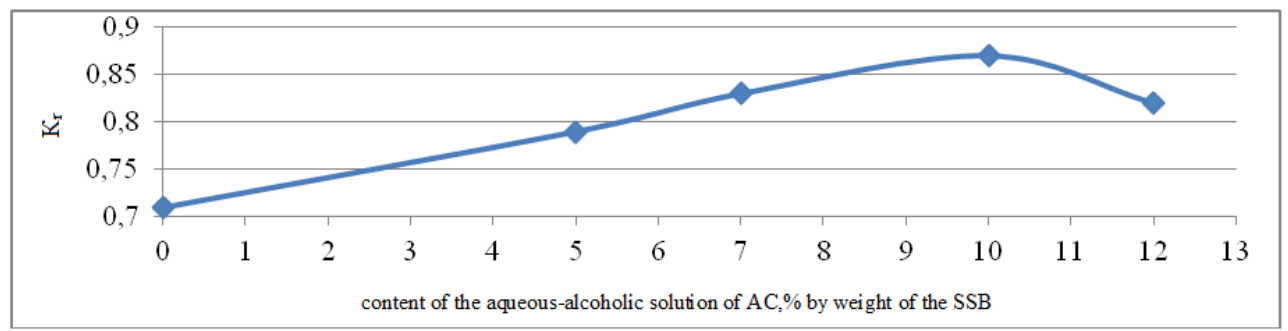

Fig. 3. Water resistance of granules depending on the content of an aqueous-alcoholic solution of AC, $\%$ by weight of SSB

RFA data show that the silicate system modified with aqueous alcoholic solution ACs as opposed to aqueous solution ACs is completely amorphous (Figure 4).

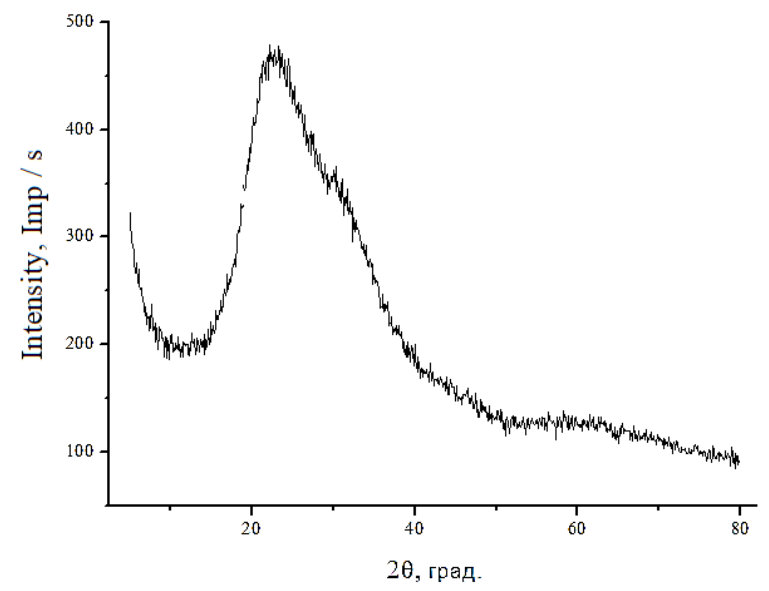

Fig. 4. Diffraction pattern of a sample based on SSB modified with a water-alcohol solution of AC 
Therefore, it can be concluded that the connections of type $\mathrm{Zn}_{2} \mathrm{SiO}_{4} \mathrm{H}_{2} \mathrm{O}, \mathrm{ZnSiO}_{3}$, etc. are in amorphous state. The absence of a crystalline phase of water-soluble sodium acetate may be due to the following processes. It is most likely that the modifying solution produces appropriate ether from the interaction of acetic acid and ethyl alcohol. The resulting ether is not hydrolyzed in the SNA system to acetic acid and thus is evaporated during the microwave process. It should be noted that the modified sodium silicon diffractogram also shows a large amount of amorphous phase, but there are reflexes characteristic of the $\mathrm{NaF}$ and $\mathrm{SiF}_{6}$ phases, traces of $\mathrm{ZnO}$.

\section{Conclusions}

Thus, it is shown that by improving the structural formation processes by means of directed modification of the SSB by an aqueous-alcoholic solution of zinc acetate, the thermal performance of granulated thermal insulation material can be substantially improved. The scientific answer lies in the development of ideas about the mechanism of formation of sparingly soluble complexes when modifying sodium silicate binders with zinc-containing solutions (water and water-alcohol).

It is shown that the properties of the thermally expanded granular material can be controlled by changing the composition of the zinc acetate solvent. The structure-forming ability of alcohols is manifested in a change in the viscosity of sodium silicate binders and increases with a decrease in the surface tension, dielectric constant, and dipole moment of the alcohol; in the porization of the hydrogel due to the evaporation of alcohol from the intermicellar liquid during heating.

It is shown that the improvement of the thermal characteristics of porous granules expanded upon microwave heating is achieved by modifying the binder with a $20 \%$ aqueous-alcoholic solution. An aqueous solution of ethyl alcohol as a solvent provides the required concentration of zinc acetate in the solution when modifying the binder, which leads to an increase in the water resistance of the granules (by 20-23\%). The modifying solution significantly reduces the degree of filling the composition with finely dispersed flask, which ensures a decrease in the bulk density of the granules.

According to the results of X-ray it was found that the system SNS - an aqueousalcoholic solution of zinc acetate is amorphous. Therefore, it can be concluded that compounds of the type $\mathrm{Zn}_{2} \mathrm{SiO}_{4} \mathrm{H}_{2} \mathrm{O}, \mathrm{ZnSiO}_{3}$ are in an amorphous state.

The obtained research results made it possible to determine the rational composition of the granular heat-insulating material. Granular thermal insulation material has increased functional and operational properties: $\rho=200-280 \mathrm{~kg} / \mathrm{m}^{3}, \lambda=0.052-0.063 \mathrm{~W} /\left(\mathrm{m}^{\circ} \mathrm{C}\right)$, $\mathrm{R}=1.3-1.8 \mathrm{MPa}, \mathrm{K}_{\mathrm{r}}=0.89-0.92, \mathrm{~W}=16-18 \%$.

\section{Reference}

1. V. I. Korneev, V. V. Danilov, ZHidkoe i rastvorimoe steklo, 216 (Strojizdat, SPb, 1996)

2. A. I. Kudyakov, N. A. Svergunova., M. YU. Ivanov, Zernistyj teploizolyacionnyj material na osnove modificirovannoj zhidkostekol'noj kompozicii, 204 (TGASU, Tomsk, 2009)

3. A. S. Brykov, Silikatnye rastvory i ih primenenie, 54 (SPbGTI (TU), SPb, 2009)

4. M. M. Sychev, Neorganicheskie klei, 152 (Himiya, Leningrad, 1986)

5. B. D. Toturbiev, Stroitel'nye materialy na osnove silikat-natrievyh kompozicij, 208 (Strojizdat, Moskva,1988) 
6. I. V. Ryzhkov, B. C. Tolstoj, Fiziko-himicheskie osnovy formirovaniya svojstv smesej s zhidkim steklom, 140 (Vishcha shkola, Har'kov, 1975)

7. V. M. Hrulev, Polimersilikatnye kompozicii v stroitel'stve, 76 (TAU, UFA, 2002)

8. A. N. Grishina, E.V. Korolev, ZHidkostekol'nye stroitel'nye materialy special'nogo naznacheniya: monografiya, 222 (MGSU, Moskva, 2015)

9. P. G. Kudryavcev, O. L. Figovskij, Nanomaterialy na osnove rastvorimyh silikatov, 165 (LAP Lambert Academic Publishing, 2014)

10. N. I. Malyavskij, O. V. Dushkin, N. V. Velikanova, Vestnik MGSU, 1, 167-169 (2007)

11. R. Ajler, Kolloidnaya himiya kremnezyoma i silikatov, 1127 (Mir, Moskva, 1982)

12. B. A. Rzhanicyn, Himicheskoe zakreplenie gruntov $v$ stroitel'stve, 263 ( Strojizdat, Moskava, 1986)

13. V. I. Sidorov, N. I. Malyavskij, B. V. Pokid'ko, Izvestiya vuzov. Stroitel'stvo, 8, 27-28 (2002)

14. V. I. Loganina, S. N. Kislicyna, M.A. Sadovnikova, Stroitel'nye materialy, 4, 87-89 (2014)

15. YU. G. Ivashchenko, I. L. Pavlova, M. P. Kochergina, Resursoenergoeffektivnyye tekhnologii v stroitel'nom komplekse regiona, 11, 217-220 (2019)

16. Ivaschenko Y., Kochergina M., Pavlova I., E3S Web of Conferences (FORM 2019)

17. YU. G. Ivashchenko, I. L. Pavlova, M. P. Kochergina, NAU. Ezhemesyachnyj nauchnyj zhurnal, 1, 6, 116-118 (2015)

18. U. G. Ivashchenko, I. L. Pavlova, M. P. Kochergina, Patent RU 2623754 (2016, Byul. 10)

19. YU. G. Ivashchenko, I. L. Pavlova, M. P. Kochergina, Vestnik VolgGASU, 43, 62, 66-76 (2016)

20. Yu.S. Shabarov, Organicheskaya khimiya, 848 (Lan', SPb, 2011) 